\title{
Pengaruh Resolusi 3D CAD STL Pada Kualitas Geometri dan Dimensi (G\&D) Produk Pola Cor 3D Printer
}

\author{
Muhammad Munadi ${ }^{*}$, Hamid Abdillah ${ }^{2}$ \\ 1, 2 Program Studi Teknologi Pengecoran Logam, Politeknik Manufaktur Ceper \\ 1,2Jln. Batur Tegalrejo Ceper, Klaten, Jawa Tengah, 57465 Indonesia \\ E-mail: m.munadipolman@gmail.com ${ }^{1}$, vici.hamid@gmail.com ${ }^{2}$
}

\section{Info Naskah:}

Naskah masuk: 2 Juni 2020

Direvisi: 27 Juli 2020

Diterima: 13 Agustus 2020

\begin{abstract}
Abstrak
3D printer merupakan teknologi rapid prototyping yang telah berkembang pesat dalam decade ini. 3D printer menggunakan STL file yang berasal dari gambar 3D CAD sebagai input data untuk proses pengerjaan. Penelitian ini bertujuan untuk mengetahui pengaruh dari resolusi STL file yang digunakan terhadap kualitas geometri dan dimensi (G\&D) dari produk yang dihasilkan. Penelitian ini dilakukan dengan menggunkaan 2 jenis resolusi STL file yang dibuat dengan Autodesk Inventor. Hasil penelitian memperoleh informasi bahwa terdapat pengaruh dari resolusi STL file yang digunakan terhadap kualitas geometeri dan dimensi produk yang dibuat. Pada kualitas geometeri produk memiliki perbedaan bentuk geometri pada bagian yang berbentuk radius. Sedangkan pada aspek dimensi produk diperoleh ketelitian dimensi produk 0.02-0.8 $\mathrm{mm}$.
\end{abstract}

\section{Keywords:}

STL;

3D printer;

casting pattern.

\begin{abstract}
3D printer is a rapid prototyping technology that has developed rapidly in this decade. 3D printers use STL files derived from 3D CAD drawings as input data for the processing. The purpose of this study is to determine the effect of the resolution of the STL file used on the quality of the geometry and dimensions (G\&D) of the product produced. This research was conducted by using 2 types of STL file resolution created with Autodesk Inventor. The results of this study are that there is an influence of the resolution of the STL file used on the quality of the geometry and dimensions of the product being made. the quality of the product geometry has different geometric shapes in the radius. Whereas in the aspect of the product dimension obtained a product dimension accuracy of $0.02-0.8$ $\mathrm{mm}$.
\end{abstract}




\section{Pendahuluan}

Pembuatan pola cor sebagian besar dilakukan dengan pekerjaan manual dan menghabiskan sekitar $70 \%$ dari total waktu produksi dengan metode cor logam[1]. Pola cor merupakan replika dari benda yang akan buat melalui proses cor. Pola cor dituntut untuk memiliki bentuk geometeri dan ketelitian dimensi yang baik. Pola cor dengan geometri dan ukuran yang teliti dapat meminimalkan cacar cor dan meningkatkan kualitas geometeri dan dimensi dari produk cor [2].

3D printer merupakan salah satu teknologi rapid prototyping (RP) yang kini semakin populer dan berkembang pesat sejak pertama kali ditemukan pada tahun 1989. Saat ini, penggunaan 3D printer telah mencakup berbagai bidang seperti kesehatan, teknik, seni dan pendidikan. Perkembangan lain dalam 3D printer adalah berbagai jenis proses pembuatan produk seperti Stereolithigrapy (SLA), Digital Light Procesing (DLP), Fused Deposid Material (FDM), Selective Laser Sintering (SLS) dan yang lainnya [3].

3D printer bekerja berdasarkan dari data 3D CAD yang dikonversikan ke STL file yang kemudian digunakan sebagai $G$-Code untuk pergerakan $3 \mathrm{D}$ printer [4]. Singkatnya proses pengerjaan, menjanjikan kecepatan dalam waktu pengerjaan. Selain itu 3D printer juga memiliki kemampuan untuk melakukan pembuatan produk dengan tingkat komplektifitas bentuk geometri yang tinggi. Oleh karena itu teknologi 3D printer dapat membantu pekerjaan dalam sector pengecoran logam untuk lebih efektif dan efisien dalam waktu dan kualitas pengerjaan [5], [6].

Pembuatan STL file menjadi langkah pertama dalam penggunaan teknologi ini [7]. STL menjadi referensi tunggal dalam proses pembuatan produk dengan 3D printer. Dengan kata lain kualitas dari STL file yang digunakan, mempengaruhi kualitas dari produk yang dihasilkan[8]. Banyak masalah yang mempengaruhi kualitas dari STL file [9],[10]. Penelitian-penelitian sebelumnya, fokus penelitian adalah mengkaji prihal ketelitian dimensi[11]-[13] dan kualitas permukaan produk [14] dengan variasi berbagai jenis 3D printer dan parameter yang digunakan.

Penelitian ini bertujuan untuk mengkaji pengaruh dari resolusi STL file yang digunakan terhadap kualitas geometeri dan dimensi dari produk pola cor yang dihasilkan.

\section{Metode Penelitian}

\subsection{Alat dan Bahan}

Penelitian ini menggunakan 3D printer dengan sistem DLP. kapasitas produksi dari 3D printer ini adalah 65x90x150 mm. Material yang digunakan untuk mencetak produk adalah resin UV $405 \mathrm{~nm}$ dengan warna putih untuk STL file resolusi high dan warna kuning untuk STL file resolusi brep. Parameter print yang digunakan adalah kualitas medium untuk seluruh spesimen print.

Tahapan metode yang dilakukan dalam penelitian mengenai pengaruh kualitas STL terhadap produk pola cor dengan 3D printer diperlihatkan seperti pada Gambar 1.

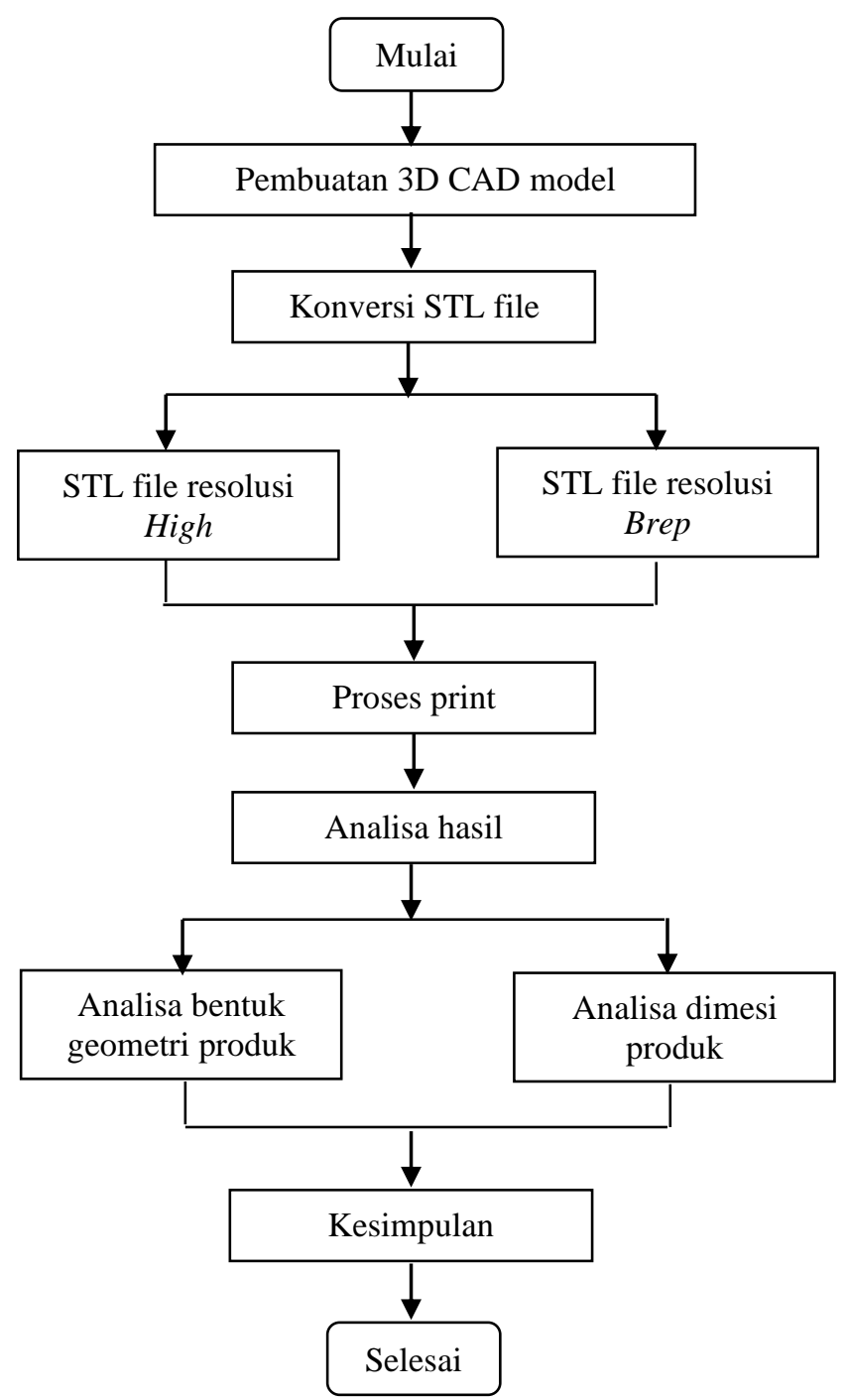

Gambar 1. Diagram Alir Penelitian yang Dilakukan

\subsection{Standar Triangle Language (STL) File}

STL file merupakan standar de facto dalam RP. STL merupakan format komersil pertama dalam addtitive Manufacture (AM) yang diproduksi oleh 3D System pada tahun 1987 [15]. STL merupakan singkatan dari STereoLithography, tetapi terkadang juga di artikan sebagai Standard Triangle Language atau Standar Tesellation Language [16].

STL file dihasilkan dari data 3D CAD yang melalui proses save as atau export. STL file dapat dihasilkan dalam betuk format binary atau ASCII (teks)[17]. Output dari proses ini berupa berupa tampilan 3D dengan mesh berbentuk segitiga. Pada file STL, permukaan solid gambar 3D CAD ditampilan menggunakan permukaan segitiga dengan titik vektor di luar permukaan dari 3D solid. Contoh dari permukaan yang menggunakan STL format dapat dilihat pada Gambar 1 [18], [19]. Gambar 2 (a) merupakan tampilan 3D CAD yang belum dilakukan meshing. Gambar 2 (b) merupakan hasil meshing 3D CAD dengan kualitas kasar dan gambar 2 (c) merupakan gambar 3D CAD dengan meshing dengan kualitas halus. 


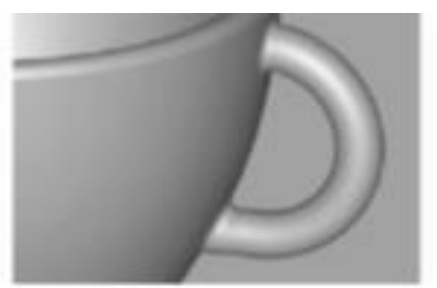

(a)

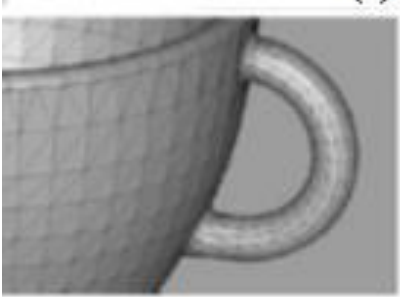

(b)

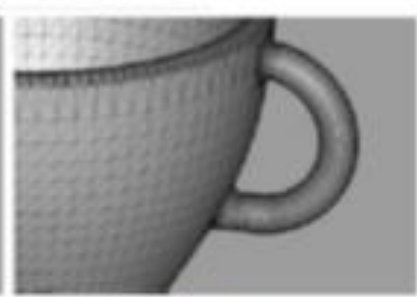

(c)
Gambar 2. Contoh STL File[17]

\subsection{Analisis Data}

Analisa yang dilakukan adalah analisa kualitas geomteri produk dan dimensi produk. Analisa gemoteri produk dimaksudkan untuk mengkaji bentuk dan kehalusan produk. Analisa ini dilakukan secara visual dengan mengacu pada standar kualitas produk pola cor.

Analisa dimensi produk dilakukan untuk mengkaji ketelitian dari dimensi produk yang dihasilkan. Analisa ini dilakukan dengan cara mengukur bagian-bagian produk dengan alat ukur presisi (jangka sorong digital). Bagianbagian produk yang diukur ditampilkan dalam Gambar 3.

Dalam analisa ini setiap bagian dari produk dilakukan pengukuran sebanyak 3 titik yang kemudian dirata-rata. Hal ini dilakukan untuk melihat kesamaan dimensi pada satu bagian sekaligus penguat untuk menetukan kualitas geomteri dari produk. Hasil rata-rata tersebut kemudian digunakan untuk menghitung besarnya penyimpangan yang terdiri. Nilai penyimpangan tersebut kemudian dibandingkan dengan nilai toleransi umum ISO 27681:1989 [20] sebagai penentu apakah penyimpangan yang terjadi masuk (GO) atau tidak (NO GO) dalam daerah toleransi. Dalam penelitian daerah tolerasi ISO yang digunakan adalah fine.

Sedangkan untuk perhitungan besarnya draft angle yang dihasilkan dihitung dengan rumus (1) mengenai arctangen [21]. Data hasil pengukuran kemudian disajikan secara deskriptif dan dibandingkan dengan ukuran acuan (gambar teknik).

$$
\text { Draf Angle }=\text { ArcTan }((\mathrm{F} 1-\mathrm{F} 2) / 2) / \mathrm{C}
$$

dimana,

$\begin{array}{ll}\text { Drat Angle } & \text { : kemiringan pola cor } \\ \text { ArcTan } & \text { : arc tangen } \\ \text { F1 } & \text { : lebar bawah pola } \\ \text { F2 } & \text { : lebar atas pola } \\ \text { C } & \text { : tinggi pola }\end{array}$
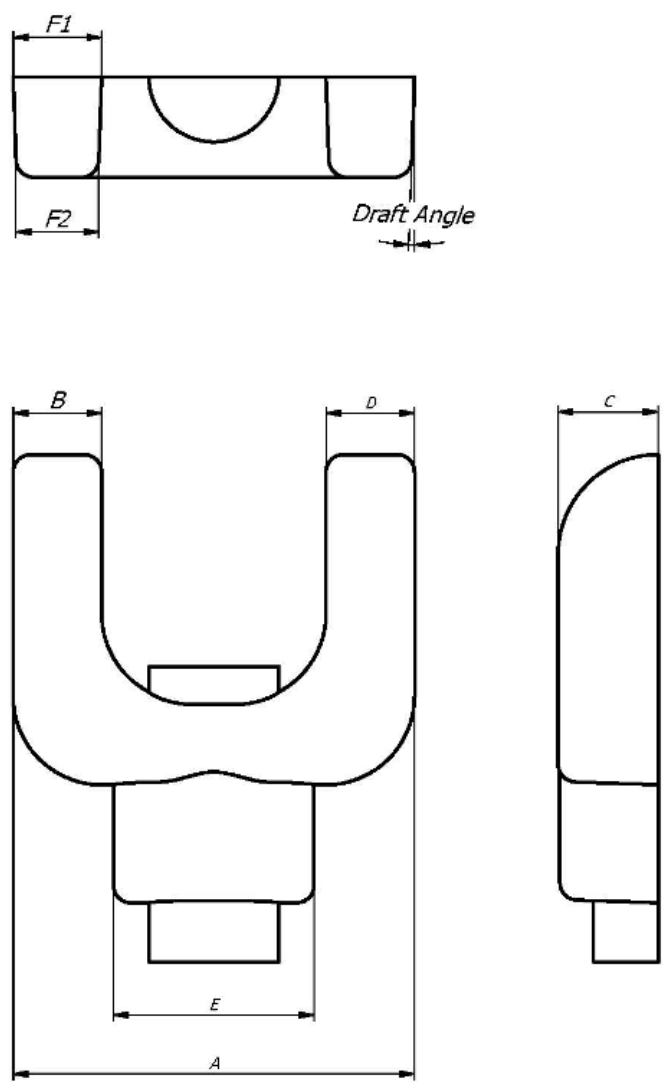

Gambar 3. Bagian-Bagian Produk Yang Akan Diukur

\section{Hasil Dan Pembahasan}

\subsection{Desain dan Konversi STL File}

Proses desain dan konversi STL file dilakukan dengan menggunakan software Autodesk Inventor Profesional 2019 Education Version. Produk yang akan dibuat adalah fork. Fork merupakan komponen sambungan transmisi yang tidak konsentris (satu sumbu) dan memiliki bentuk sederhana. Produk ini memiliki ukuran mayor 86 x 68 x 34 $\mathrm{mm}$.

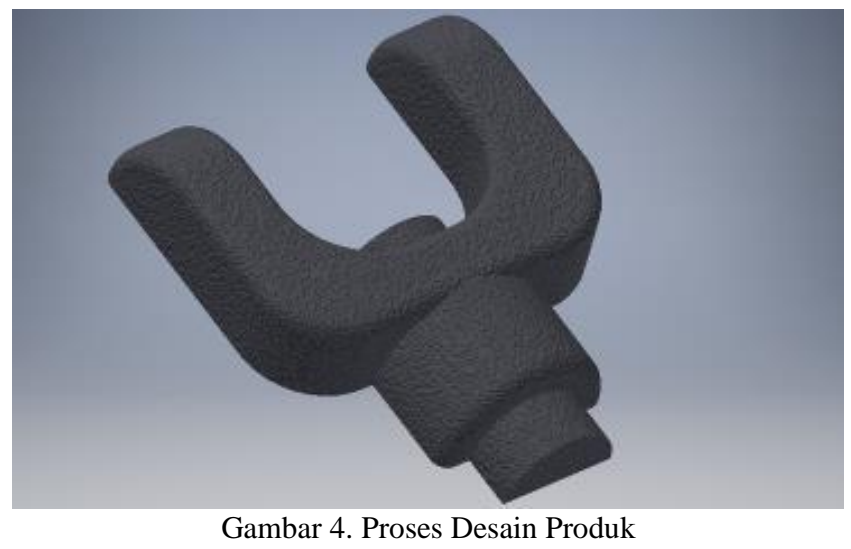

Setelah proses desain selesai dilakukan, kemudian dilanjutkan dengan proses konversi hasil 3D desain ke STL file. Proses konversi lakukan dengan menggunakan software yang sama. Langkah konversi dilakukan dengan melakukan"save as" dengan ektensi format .stl yang 
kemudian dilanjutkan dengan pengaturan parameter kualitias dan resolusi STL file.

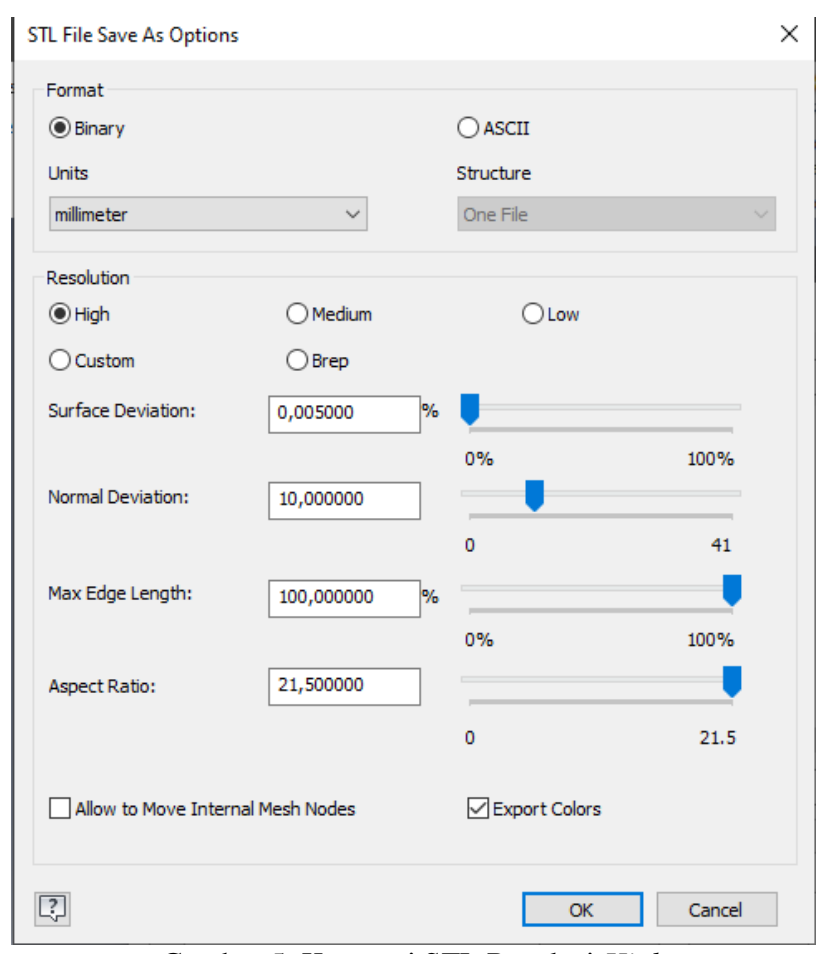

Gambar 5. Konversi STL Resolusi High

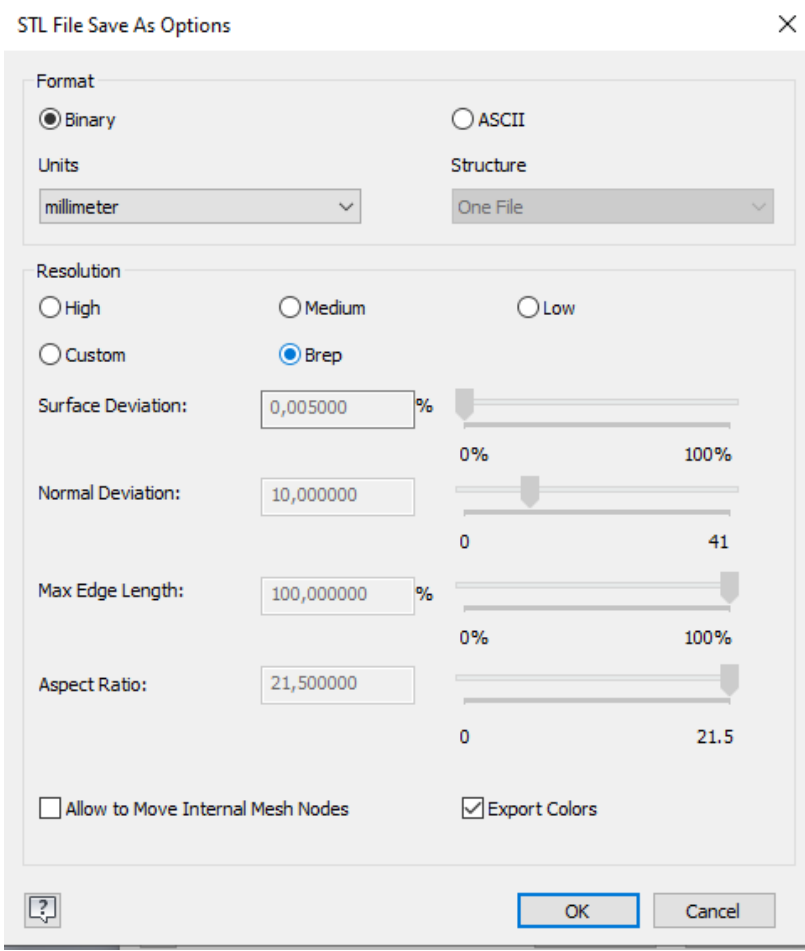

Gambar 6. Konversi STL Resolusi Brep

Sesuai dengan rancangan metode dan tujuan penelitian ini, resolusi dari STL yang digunakan adalah high dan brep. Detal dari masing-masing pengaturan disesuaikan dengan bawaan dari software gambar yang digunakan seperti diperlihatkan pada Gambar 5 dan Gambar 6. Setelah proses konversi ke STL file selesai, STL file untuk resolusi high memiliki ukuran file sebesar 1,272 KB (1,2 MB) atau setara dengan 3.473.408 pixel (3,4 megapixel), sedangkan STL file dengan resolusi brep memiliki ukuran file sebesar 250 $\mathrm{KB}$ atau setara dengan $682.666,6$ pixel (0,6 megapixel).

Perbedaan ukuran file ini dipengaruhi oleh ukuran meshing yang dilakukan. Semakin kecil meshing yang digunakan akan berimplikasi pada jumlah vektor segitiga yang digunakan, yang kemudian juga akan semakin menambah byte dari file tersebut. Gambar 10 menampilkan secara visual hasil perbedaan ukuran resolusi meshing yang digunakan. Pada gambar 10a STL file menggunakan ukuran vektor segitiga kecil (high). Sedangkan pada gambar 10b STL file menggunakan ukuran vektor segitiga besar.

\subsection{Printing}

Proses printing dilakukan setelah file STL hasil konversi telah siap. STL file kemudian di input dalam software slicing anycubic photon slicing v1.6 untuk digenerate sebagai G-Code untuk proses printing. Anycubic photon slicing v1.6 merupakan software slicing bawaan dari perangkat 3D printer. Paramter print yang digunakan merupakan parameter print dengan kualitas normal seperti ang ditampilkan pada Gambar 7.

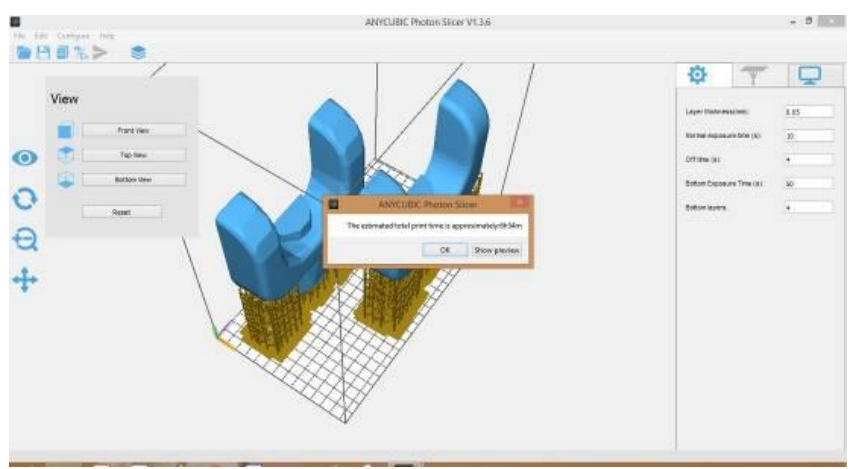

Gambar 7. Proses Slicing Dan Pengaturan Parameter Printing

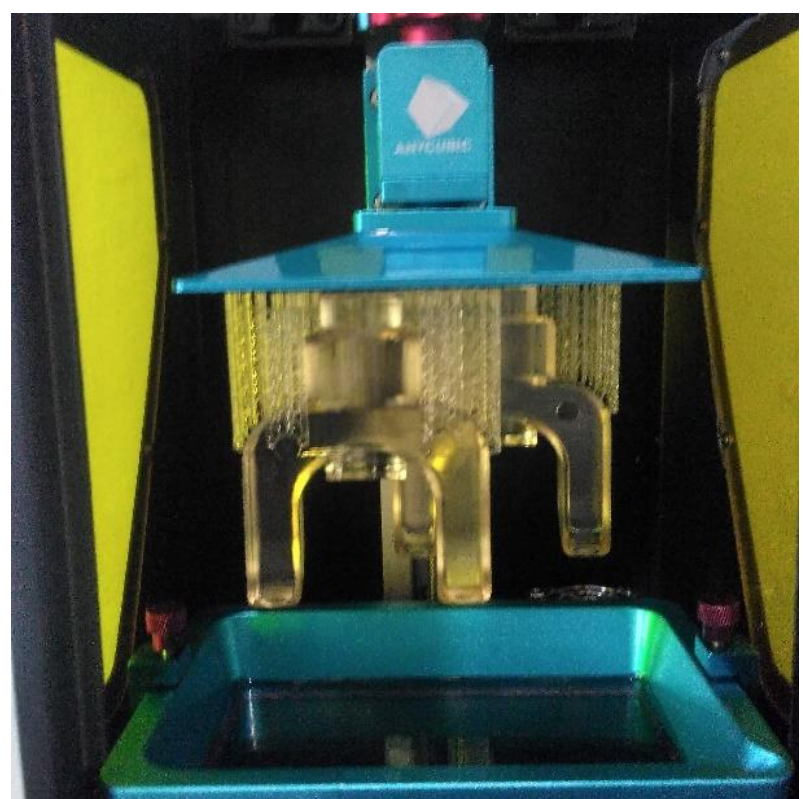

Gambar 8. Proses printing produk dengan material resin UV $405 \mathrm{~nm}$ 
Setelah pengaturan parameter selesai, dilakukan generate G-Code yang kemudian di kirimkan ke 3D printer dan dilanjutkan dengan proses printing. Dalam proses slicing, estimasi waktu print adalah 6 jam 54 menit, akan tetapi waktu printing sesungguhnnya adalah 7 jam 58 menit. Sehingga terdapat gap sebesar 1 jam 4 menit untuk waktu proses printing, prosesnya seperti ada Gambar 8 .

\subsection{Analisa Geometri Produk}

Hasil printing produk dapat pada gambar 7. Produk yang sudah selesai di print kemudian dibersihkan dengan Alkohol untuk menghilangkan sisa cairan resin yang masih menempel pada bagian padat produk. Hal ini dilakukan untuk menghindari adanya sisa cairan resin yang mengeras akibat bereaksi dengan cahaya matahari sehingga menimbulkan permukaan yang tidak rata atau perubahan bentuk geometri produk.

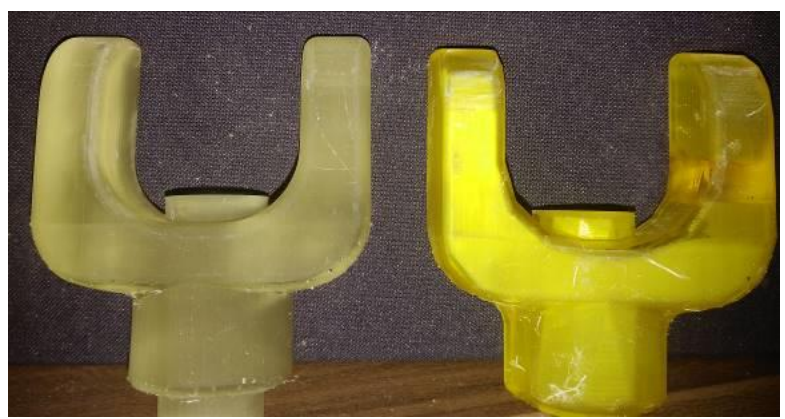

Gambar 9. Proses printing produk

Hasil produk polacor kemudian dibandingkan dengan gambar desain produk untuk melihat kesesuain bentuk dengan desain yang dibuat. Secara visual, produk memiliki bentuk yang sesuai dengan gambar desain yang dibuat. Hal ini terlihat dari bentuk produk yang utuh dan lengkap sesuai dengan gambar desain.

Selanjutnya dilakukan analisa perbandingan bentuk geometri secara mendalam pada produk yang dibuat dengan resolusi yang berbeda. Produk dengan resolusi high (selanjutnya disebut produk high) dibuat dengan cairan resin berwarna clear, sedangkan produk dengan resolusi brep (selanjutnya disebut produk brep) dibuat dengan cairan resin berwarna kuning.

Pembuatan kedua produk menggunakan material yang sama yakni resin UV $405 \mathrm{~nm}$. Selain itu parameter print yang digunakan pada kedua produk adalah sama. Sehingga pengaruh dari jenis material dan parameter print yang digunakan dapat diabaikan.

Gambar 10 menampilkan perbedaan bentuk geometeri pada bagian body produk. Pada produk high, memiliki bentuk radius luar dan dalam yg baik (A), sedangkan pada produk brep, bentuk radius dalam dan luar tidak sempurna (B). Bentuk radius tersebut menjadi menyerupai segi-n. Sedangkan pada tampilan d depan, bagian core pin pada produk high (C) memiliki bentuk setengah lingkaran yang baik. sedangkan untuk bagian core pin pada produk brep tidak terbentuk lingkaran dengan baik.

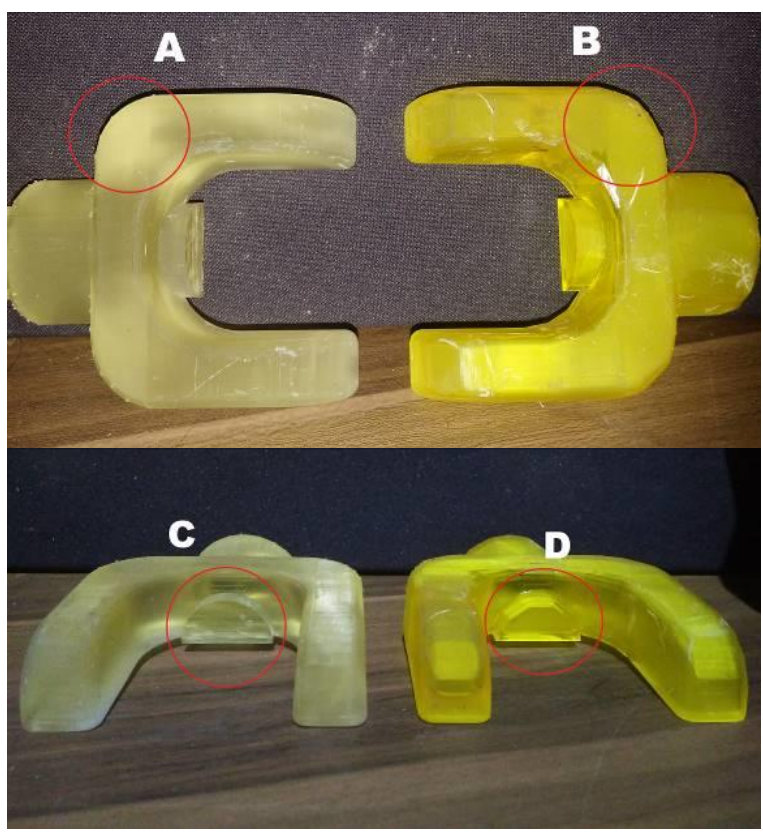

Gambar 10. Perbedaan Bentuk Geometri produk

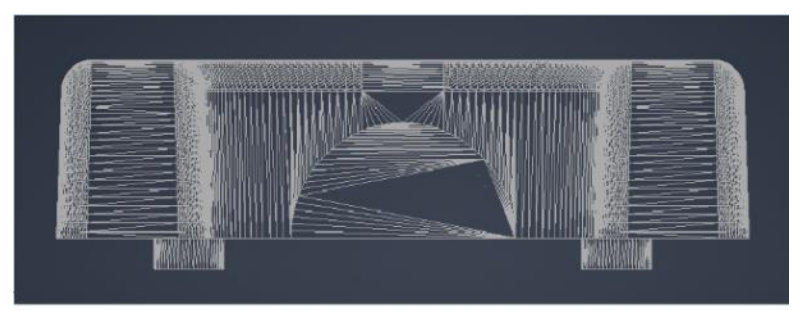

(a)

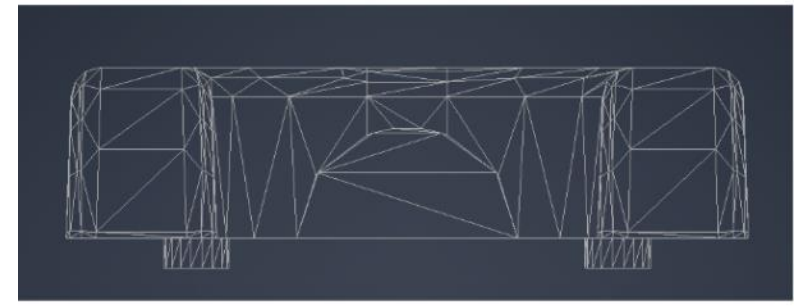

(b)

Gambar 11. Perbedaan Bentuk Geometri 3D STL produk

Perbedaan bentuk lingkaran yang dihasilkan pada produk high dan brep dikarenakan perbedaan resolusi pada saat konversi ke STL file. Perbedaan resolusi saat konversi STL file berhubungan dengan besar kecilnya deviasi permukaan dan ukuran segitiga yang digunakan pada proses meshing[22]. Semakin kecil deviasi dan ukuran segitiga yang digunakan pada saat meshing akan menghasilkan permukaan radius yang semakin baik. Selain itu, Semakin kecil ukuran segitiga mesh yang digunakan, berimplikasi pada besarnya ukuran STL file [23]. 
Tabel 1. Hasil Pengukuran Dimesi Produk

\begin{tabular}{|c|c|c|c|c|c|c|c|}
\hline \multirow{2}{*}{$\begin{array}{c}\text { Resolusi } \\
\text { STL }\end{array}$} & \multirow{2}{*}{$\begin{array}{c}\text { Hasil } \\
\text { Pengukuran }\end{array}$} & \multicolumn{6}{|c|}{ Lokasi Pengukuran } \\
\hline & & $\mathbf{A}$ & $\mathbf{B}$ & $\mathrm{C}$ & D & $\mathbf{E}$ & Draf Angle \\
\hline \multirow{5}{*}{ High } & Mean & 68,02 & 15,01 & 17,07 & 15,01 & 33,99 & 1,97 \\
\hline & Acuan & 68 & 15 & 17 & 15 & 34 & 2 \\
\hline & Penyimpangan & 0,02 & 0,01 & 0,07 & 0,01 & $-0,01$ & $-0,03$ \\
\hline & Tol. ISO [7] & $\pm 0,15$ & $\pm 0,1$ & $\pm 0,1$ & $\pm 0,1$ & $\pm 0,15$ & $\pm 0,2$ \\
\hline & Status & GO & GO & GO & GO & GO & $\mathrm{GO}$ \\
\hline \multirow{5}{*}{ Brep } & Mean & 68,89 & 15,07 & 17,17 & 15,09 & 34,18 & 1,91 \\
\hline & Acuan & 68 & 15 & 17 & 15 & 34 & 2 \\
\hline & Penyimpangan & 0,89 & 0,07 & 0,17 & 0,09 & 0,18 & $-0,09$ \\
\hline & Tol. ISO [7] & $\pm 0,15$ & $\pm 0,1$ & $\pm 0,1$ & $\pm 0,1$ & $\pm 0,15$ & $\pm 0,2$ \\
\hline & Status & NO GO & GO & $\mathrm{GO}$ & GO & NO GO & GO \\
\hline
\end{tabular}

\subsection{Analisa Dimensi Produk}

Dimensi pada sebuah produk merupakan aspek penting yang harus dipenuhi selain dari bentuk geomteri produk. Kesesuaian dimensi produk dilihat melalui perbandingan dimensi produk dengan dimensi desain acuan dan toleransi dimensi yang digunakan. Dimensi produk yang baik dan standar juga berperan penting dalam meminuhi sifat interchangeable atau kemampuan bongkar pasang dengan komponen lainnya. Data hasil pengukuran dan validasi dimensi produk high dan brep disajikan pada Tabel 1.

Pada tabel 1 ditunjukan bahwa pada produk high memiliki penyimpangan pada antara 0,01-0,07 pada dimensi linier dan -0,03 pada dimensi sudut. Dengan besaran penyimpangan tersebut, untuk produk high masuk dalam katergori GO untuk ketercapaian dimensi produk menurut standar ISO.

Produk brep sebagian besar dimensi linier dan sudut produk masuk dalam batas penyimpangan produk ISO [20]. Tetapi untuk dimensi major (terluar produk) seluruhnya tidak masuk batas penimpangan karena melebihi batas maksimal penyimpangan yang diijinkan sehingga masuk dalam kategori NO GO. Hal ini terjadi dikarenakan penyimpangan ukuran produk sebesar $0,89 \mathrm{~mm}$ dan penyimpangan ini berada diluar batas toleransi ISO yakni $\pm 0,15$. Artinya, produk mengalami pembesaran dimensi saat proses konversi STL File. pembesaran ini dipengaruhi oleh ukuran resolusi STL file. STL file dengan resolusi brep menggunakan ukuran vector segita yang besar, sehingga proses konversi bentuk geometeri dari 3D CAD ke STL mengalami pembesaran terutama pada bagian yang berbentuk radius. Oleh karena itu, produk brep tidak di rekomendasikan untuk digunakan. Hal ini menujukan bahwa resolusi STL file yang digunakan juga mempengaruhi ketelitian dimensi dari produk yang dihasilkan [24].

\section{Kesimpulan}

Berdasarkan pembahasan diatas dapat disimpulkan bahwa resolusi yang digunakan dalam proses konversi ke STL file memiliki pengaruh pada geometeri dan dimensi produk yang dihasilkan. Produk yang memiliki kualitas geometeri dan dimensi yang baik dapat dicapai dengan menggunakan resolusi yang tinggi dalam konversi STL file. sehingga deviasi dan ukuran segitiga pada proses meshing menjadi lebih kecil. Semakin kecil deviasi dan ukuran segitiga meshing yang digunakan, semakin besar pula ukuran STL file yang dihasilkan.

\section{Daftar Pustaka}

[1] D. Pal and B. Ravi, "Rapid tooling route selection and evaluation for sand and investment casting," Virtual Phys. Prototyp., vol. 2, no. 4, pp. 197-207, 2007.

[2] H. Abdillah and U. Ulikaryani, "Hybrid Manufacturing and Rapid Prototyping in Metal Casting Industry: A Review," 2020, doi: 10.4108/eai.20-9-2019.2290957.

[3] D. Pham and S. S. Dimov, Rapid manufacturing: the technologies and applications of rapid prototyping and rapid tooling. Springer Science \& Business Media, 2012.

[4] S. E. Zeltmann, N. Gupta, N. G. Tsoutsos, M. Maniatakos, J. Rajendran, and R. Karri, "Manufacturing and security challenges in 3D printing," Jom, vol. 68, no. 7, pp. 1872$1881,2016$.

[5] M. Upadhyay, T. Sivarupan, and M. El Mansori, "3D printing for rapid sand casting-A review," J. Manuf. Process., vol. 29, pp. 211-220, 2017.

[6] S. R. Sama, T. Badamo, and G. Manogharan, "Case Studies on Integrating 3D Sand-Printing Technology into the Production Portfolio of a Sand-Casting Foundry," Int. J. Met., vol. 14, no. 1, pp. 12-24, 2020.

[7] K. M. Griffith, R. de Cataldo, and K. H. Fogarty, "Do-ityourself: 3D models of hydrogenic orbitals through 3D printing," J. Chem. Educ., vol. 93, no. 9, pp. 1586-1590, 2016.

[8] T. Cai et al., "The residual STL volume as a metric to evaluate accuracy and reproducibility of anatomic models for 3D printing: application in the validation of 3D-printable models of maxillofacial bone from reduced radiation dose CT images," 3D Print. Med., vol. 1, no. 1, pp. 1-9, 2015.

[9] A. K. Kamrani and E. A. Nasr, Engineering design and rapid prototyping. Springer Science \& Business Media, 2010.

[10] R. Udroiu and A. Nedelcu, "Optimization of additive manufacturing processes focused on 3D Printing," Rapid Prototyp. Technol. Funct. Requir. Hoque, ME, Ed, pp. 1-28, 2011.

[11] C. Iancu, "ABOUT 3D PRINTING FILE FORMATS.," Ann. Constantin Brancusi Univ. Targu Jiu-Letters Soc. Sci. Ser., no. 2, 2018. 
[12] C. R. Hatz, B. Msallem, S. Aghlmandi, P. Brantner, and F. M. Thieringer, "Can an entry-level 3D printer create highquality anatomical models? Accuracy assessment of mandibular models printed by a desktop 3D printer and a professional device," Int. J. Oral Maxillofac. Surg., vol. 49, no. 1 , pp. 143-148, 2020.

[13] M. Odeh et al., "Methods for verification of 3D printed anatomic model accuracy using cardiac models as an example," 3D Print. Med., vol. 5, no. 1, p. 6, 2019.

[14] E. George, P. Liacouras, F. J. Rybicki, and D. Mitsouras, "Measuring and establishing the accuracy and reproducibility of 3D printed medical models," Radiographics, vol. 37, no. 5, pp. 1424-1450, 2017.

[15] P. F. Jacobs, Stereolithography and other RP\&M technologies: from rapid prototyping to rapid tooling. Society of Manufacturing Engineers, 1995.

[16] D. Chakravorty, "STL File Format (3D Printing) - Simply Explained," 2019. https://all3dp.com/what-is-stl-file-formatextension-3d-printing/.

[17] I. Gibson, D. W. Rosen, B. Stucker, and others, Additive manufacturing technologies, vol. 17. Springer, 2014.

[18] A. K. Kamrani and E. A. Nasr, Rapid prototyping: theory and practice, vol. 6. Springer Science \& Business Media, 2006.

[19] D. Um, Solid modeling and applications. Springer, 2015.

[20] D. I. N. ISO, "2768-1: 1991-06, Allgemeintoleranzen; Toleranzen für Längen-und Winkelmaße ohne einzelne Toleranzeintragung," Gen. Toler. linear angular Dimens. without Individ. Toler. Indic., pp. 2762-2768, 1989.

[21] K. A. Stroud, Engineering mathematics: programmes and problems. Macmillan International Higher Education, 2016.

[22] I. Onyeako and W. Lee, "Resolution-aware Slicing of CAD Data for 3D.," in VISIGRAPP (1: GRAPP), 2016, pp. 124 129.

[23] C. K. Chua, C. H. Wong, and W. Y. Yeong, Standards, quality control, and measurement sciences in $3 D$ printing and additive manufacturing. Academic Press, 2017.

[24] S. Leng et al., "Anatomic modeling using 3D printing: quality assurance and optimization," 3D Print. Med., vol. 3, no. 1, p. 6, 2017. 